\title{
Kurumsal İktisatta Açılan Yeni Bir Pencere: Douglass C. North Perspektifinden Kurumların Değerlendirilmesi ${ }^{1}$
}

\author{
Merve YOLAL EROĞLU*
}

ÖZ

$\mathrm{Bu}$ çalışmanın amacı, ekonomik ve kurumsal değişimi değerlendirirken “cliometrics” (iktisat teorisi ve niceliksel metotların tarih araştırmalarına uygulanması)alanda yaptığı öncü çalışmaları ve kurumsal iktisat alanına sağladığı katkılarından dolayı 1993 yılında Nobel Ekonomi Ödülü' ne layık görülen Douglass C. North'un kurumlar hakkındaki düşüncelerini açıklamaktır. Çalışmada, Yeni Kurumsal İktisata farklı bir bakış açısı getiren DouglassCecil North'un perspektifinden kural ve kurum olgusu, kurumsal yapıya bağlı olarak değişen ve ekonomik performansı etkileyen işlem maliyetleri ve mülkiyet hakları konusu ile kurumsal değişimin nedenleri ve kurumsal değişimin ekonomik performans üzerindeki etkileri incelenecektir.

Anahtar Kelimeler: Kurum, Ekonomik Büyüme, İşlem Maliyetleri ve Mülkiyet Hakları

JEL Sınıflandırması: B15, B25, K11, O11

\section{A New Window Opened at Institutional Economy: Evaluation of the Institutions in the bDouglass C. North Perspective}

\begin{abstract}
The aim of this study is to explain the judgments on the institutions of Douglass C. North, whose was awarded the Nobel Prize in 1993 for his pioneering studies in the field of "cliometrics" (application of economic theory and quantitative methods to historical researches) field while evaluating the economic and the institutional change and for his contributions to the field of the institutional economics. In the study, the concept of rules and institutions, transaction costs and property rights that change depending on the institutional structure and affect economic performance, the reasons of the institutional change and the effects of the institutional change on the economic performance isexamined with the perspective of Douglass Cecil North, who presents a different point of view to New Institutional Economics.
\end{abstract}

Keywords: Institution, Economic Growth, Transaction Costs and Property Rights

JEL Classification: B15, B25, K11, O11

Geliş Tarihi /Received: 06.02.2018 Kabul Tarihi / Accepted: 03.05.2018

1 Bu çalışma, 2017 yılında Dokuz Eylül Üniversitesi Sosyal Bilimler Enstitüsü Maliye Anabilim Dalı'nda savunulmuş olan "Hayek, Buchanan ve North: Üç Nobel Ekonomi Ödülü Sahibinin Kurallar ve Kurumlar Üzerine Düşünceleri: Analiz ve Değerlendirmeler” başlıklı yüksek lisans tezinden yararlanılarak hazırlanmıştır.

* Arş. Gör., Dokuz Eylül Üniversitesi, İktisadi ve İdari Bilimler Fakültesi, Maliye Bölümü, merve.yolal@deu.edu.tr, ORCID: 0000-0001-5980-5610 


\section{GİRIŞ}

Douglass C. North, ekonomik ve kurumsal değişimi açıklamak için iktisat teorisi ve niceliksel yöntemleri uygulayarak iktisat tarihine yeni bir bakış açısı getirdiği için 1993 yılında Nobel Ödülü sahibi olmaya hak kazanmıştır. Douglass North, Yeni Kurumsal İktisadın temelini oluşturan Neo-klasik iktisadın "neden bir ülke fakir kalırken diğer ülkelerin zengin olduğu" sorusunun cevabını kurumlar ve kurumsal değişim olarak ifade etmektedir. North, sosyal bilimler genelinde kurumları güçlü bir katalizör görevi görerek, çeşitli biçimlerde ele alınmasına olanak tanımıştır. North, mevcut teorilerin hiçbirininiktisat tarihinin değişim dinamiklerini analiz etmek için yeterli bir çerçeve sağlamadığını ve kurumların rolüne dair güçlü bir kuramsal çerçevenin olmayışını eleştirmektedir (Milonakis ve Fine, 2007: 28).North’a göre, Yeni kurumsal iktisat ile Neo-klasik iktisat teorisi arasındaki ortak zemin, kitlık dolayısıyla rekabete dayanan bir varsayımın kabul edilmesidir. North, ekonomiyi kısıtlamalara tabi bir seçim teorisi olarak görmektedir. Kurumların analizinin önemli bir parçası olarak fiyat teorisini kullanmaktadır ve kurumsal değişimi tetikleyen önemli bir güç olarak göreli fiyatlarda değişiklikleri kabul etmektedir. Douglass North, Neo-klasik iktisadın eksiklikleri ile başa çıkabilmek için analitik bir "yeniden yapılandırma" ("retooling") gerektirdiğini kabul etmektedir. Bu düşüncesini ise şu sözleri ile ortaya koymaktadır: "Yeniden yapılandırma", akademik hayatımı radikal bir şekilde değiştirdi. Çünkü Neo-klasik iktisat teorisinin araçlarının, Avrupa ekonomilerini ortaçağdan ileriye doğru tanımlayan temel toplumsal değişimi açıklayamayacağına ikna oldum.” (Milonakis ve Fine, 2007: 30).

Douglass C. North'un iktisadi analize sağlamış olduğu katkısı, iktisat tarihinde yapılan uygulamaların ve yol bağımlılı̆̆ının; kurumsal değişimin önemli bir bileşeni olarak teorik bir çerçevede formüle etmesi olmuştur. Bu ayrıca ekonomik performans konusunda yeni ve önemli bir anlayışınortaya çıkmasını sağlamıştır. Diğer bir deyişle North, ekonomik gelişmenin sadece varlıklara ve tasarruf davranışlarına bağlı olmadığını hatırlatarak, ülkeler arasındaki ekonomik performansfarklılıkların, belirli kurumların ortaya çıkması ile açıklamaktadır. Böylelikle toplumların uzun vadeli ekonomik başarısını ve başarısızlığını anlamak için yeni bir pencere açılmasını sağlamıştır (Myhrman ve Weingast: 192-193). Dolayısıyla, sosyal bilimlerin farklı disiplinlerinde çeşitli iktisatçılar tarafından farklı şekillerde ele alınan kural ve kurum kavramları, Yeni Kurumsal İktisatçı olan DouglassCecil North'un perspektifinden yeni bir boyut kazanmıştır. Douglass C. North, kural kavramını tanımlarken kuralları formel kurallar ve enformel kurallar olmak üzere iki kategoriye ayırmışır. Ona göre enformel kurallar düzenli olarak tekrarlanan insan etkileşimleri sonucunda ortaya çıkan adetler, gelenekler ve tabular gibi toplumsal olarak onaylanmış davranış normları iken; formel kurallar anayasalar, yasalar, sözleşmeler, yaptırımlar şeklinde oluşan genel hukuk ve düzenlemeleri içermektedir. Kurum kavramı ise; formel ve enformel kurallardan oluşan, insanların birbirleri ile etkileşimlerini şekillendirme işlevine sahip olan oyunun kurallarıdır(North, 2002: 9, 51-64).

North'un kurumlardan sonra üzerinde durduğu ve kurumlar ile ilişkilendirdiği bir diğer konu mülkiyet hakları ve işlem maliyeti konusudur. Ona göre mülkiyet hakkı, bireylerin kendi emekleri ile elde ettikleri mallar üzerindeki haklarıdır (North, 2002: 47).Mülkiyet hakkının elde edilmesi, el değiştirmesi veya transferi nedeniyle ortaya çıkan maliyetler ise işlem maliyetleridir. İşlem maliyetlerinin belirleyen faktörlerin temelinde de çoğunlukla formel ve enformel kurallar yer almaktadır. North mülkiyet hakkı ve işlem maliyetlerinin bireylerin tasarruf ve yatırım kararlarını etkileyerek ekonomik büyüme üzerinde etkili olduğunun fark ettiği için mülkiyet haklarının iyi bir şekilde tanımlanması ve bu hakkın etkin kurumlar oluşturularak korunması gerektiğini vurgulamıştır. Mülkiyet hakkının korunması ve düşük işlem maliyetleri sayesinde ise ekonomik performansın artırılabileceğini savunmuştur(North, 2002: 90-94).North, tarihsel süreç içerisinde kurumlarda meydana gelen değişimler ve bu değişimlerin ekonomik performans üzerindeki etkilerini incelemiş̧ir. Bunu yaparken, iktisat teorisi ve niceliksel metotların tariharaştırmalarına uygulanması olarak adlandırılan "cliometrics" çalışmalar ortaya koyarak 
kurumsal analizlerini gerçekleştirmiş ve Yeni Kurumsal İktisada farklı bir boyut kazandırmıştır. Ona göre kurumlarda yaşanan değişimi anlayabilmek için öncelikle kurumların yapısı ve sahip olduğu özellikleri bilinmesi gerekmektedir(North, 2002: 48). Çünkü, kurumsal yapının içerisinde formel ve enformel kurallar bulunduğu için ekonomik performans aynı zamanda bu kurallara ve bu kurallarda yaşanacak değişimlere bağlı olarak değişim göstermektedir. Diğer bir deyişle Douglass C. North, ülkeler arasında ortaya çıkan ekonomik performans farklılıklarının temel nedenini; formel ve enformel kurallar olarak da ifade edilen kurum faktörünün belirleyici olmasına bağlamaktadır. Dolayısıyla kurallar, kurumlar, mülkiyet hakları ve işlem maliyetleri, kurumsal değişim ve ekonomik performans kavramları kurum zincirindeki halkaları oluşturmaktadır.

Yeni Kurumsal İktisada farklı bir boyut kazandıran Douglass C. North'un kurumlar hakkındaki düşüncelerine yer veren çalışmamız dört bölümden oluşmaktadır. Çalışmamızın birinci bölümünde Douglass C. North perspektifinden kural ve kurum olguları kavramsal olarak açılanacaktır. İkinci bölümde kurumsal çerçevenin bir fonksiyonu olan ve ekonomik performans ile aralarında ilişki bulunan mülkiyet hakkı ve işlem maliyeti ilişkisi ele alınacaktır. Kurumların neden ve nasıl değişim yaşadığı, kurumsal değişimi tetikleyen faktörlerin neler olduğu konusuna üçüncü bölümde değinilecektir. Dördüncü bölüme gelindiğinde ise, kurumlarda yaşanan değişimlerin ekonomik performans üzerindeki etkisi incelenecek ve sonuç bölümünde genel bir değerlendirme yapılacaktır.

\section{NORTH'A GÖRE KURAL VE KURUM KAVRAMLARI}

North kurumları, insan etkileşimini kısıtlayan, insanlar tarafindan oluşturulmuş, toplumda oynanan oyunun kuralları olarak tanımlamaktadır. Ona göre kurumlar, insan etkileşimlerini kısıtlama ve şekillendirme işlevi görmektedir. Bu kısıtlamalar, bireylerin belirli faaliyetleri yürütmek için hangi koşullar altında neleri yapıp neleri yapamayacağını içermektedir. Başka bir deyişle, kurumlar insan etkileşimlerinin bulunduğu çerçeveyi oluşturmaktadır (North, 2002: 9-12). Kurumlar, formel (yazılı) kuralların yanı sıra enformel (yazılmamış) davranış kodlarını da içermektedir. Formel kurallar anayasalar, yasalar, mülkiyet hakları, sözleşme, yaptırımlar, tüzük, genel hukuk ve düzenlemelerden oluşmaktadır. Enformel kurallar ise, düzenli olarak tekrarlanan insan etkileşimleri sonucunda ortaya çıkan adetler, gelenekler ve tabular gibi toplumsal olarak onaylanmış davranış normlarından ve içsel olarak gelen davranışsal sinırlamalardan oluşmaktadır (North, 2002: 51-64).

Enformel ve formel kuralların ortaya çıkması farklı mekanizmalar aracılığı ile gerçekleşmektedir. Bir toplumda enformel kuralların ortaya çıkması kendiliğinden etkileşim süreci ile insan eylemlerinin bir sonucudur. İnsanlar tarafından dizayn edilmekten ziyade spontane bir şekilde gerçekleşmektedir. Enformel kuralların kendiliğinden ortaya çıkması sosyal bir grupta gerçekleşen yenilik ve taklit süreciyle olmaktadır. Bireyler düzene uyarak, ahlak kurallarına uyarak ve sosyal normları benimseyerek sosyal düzenin ortaya çıkmasını sağlamaktadır. Yani, enformel kurallar bir toplumda içselleşen ve üretilen kurumlardır. Formel kurallar ise, yöneticiler arasındaki ilişkilerin gelişmesinin ürünü olarak ortaya çıkmakta ve başkaları tarafından uygulamaya konulmaktadır (Mantzavinos ve diğerleri, 2004: 79). Formel kurallar, siyasi kurallar (örneğin anayasa), ekonomik kurallar (örneğin mülkiyet hakları ve sözleşme kanunları) ve aktörler arasındaki sözleşmeden doğan anlaşmaları (örneğin satış sözleşmeleri) kapsayan bir takım kurumsal kısıtlardan oluşmaktadır (Richter, 2005: 176-177).

Formel ve enformel kurallar arasındaki ilişki büyük ölçüde birbirini tamamlamaktadır. Şöyle ki, spesifik olarak tekrarlanan durumlar için formel kuralların tasarlanması her zaman için mümkün olamayacağı için, formel olmayanları tamamlayabilmek için enformel kurallara ihtiyaç duyulmaktadır. Bir diğer deyişle, enformel kurallar, formel kurallar tarafindan düzenlenmeyen 
ve kendini tekrarlayan etkileşim sorunlarına çözüm olarak kendiliğinden meydana gelmektedir. Çünkü bu sorunlar genellikle formel kuralların bir sonucu olarak ortaya çıkmakta ve enformel kurallar da formel kurallara uyarlanmaktadır. Eğer formel kurallar toplumun enformel sosyokültürel kurallarıyla tutarlı değilse toplum üyelerinin gözünde meşruiyetten yoksun olacaklar ve belirli bir yaptırım mekanizması ile zorlanmadıkça göz ardı edilebileceklerdir. Dolayısıyla, formel kurallara bağlılık, kısmen enformel kuralların uygulanabilir olmasına dayanmaktadır. Yani, bağlantılılık ve tamamlayıcılık, kuralların karşılıklı olarak güçlendirilmesini de içerdiğinden, kurumsal sisteme belirli bir tutarlılık ve istikrar getirmektedir (Skoog, 2005: 2324).

Enformel kurallar toplumdan topluma aktarılan bilginin ve kültürün bir parçası olarak devam etmektedir. Dolayısıyla tekrarlanan insan etkileşimleri sonucunda oluşan enformel kurallar, toplum tarafindan onaylanmış davranış normları ve içsel davranış standartlarını kapsamaktadır. Buna bağlı olarak formel kurallarda görülen sık değişimler enformel kurallarda olmamaktadır. Enformel kurallardan formel kurallara geçişin kaynağına bakıldığında ise, daha az karmaşık toplumlardan daha çok karmaşık toplumlara doğru ilerlendikçe ortaya çıktığı görülmektedir. Yani, formel kısıtların aslında enformel kısıtları değiştirmek veya enformel kısıtların yerini almak amacıyla çıkarılmış olma ihtimali söz konusu olmaktadır (North, 2002: 53-65).

Formel kurallar açık bir şekilde tanımlanmış, sosyal, ekonomik ve politik sınırlandırmalardır (Hıra ve Hıra, 2000: 272). Bu nedenle, formel kuralların değiştirilmesi politik kurumlar veya politik güce sahip olanlar tarafından yapılmaktadır. Yapılan değişikliklerin toplum tarafından benimsenmesi için de belirli yaptırım mekanizmaları gerekmektedir. Buna karşın yazılı olmayan ve insan davranışlarına yön veren enformel kurumların değişimi ise, formel kurumlara göre daha zor olmaktadır (Dumludağ, 2014: 19). Bunun nedeni ise, insanların geçmişten gelen alışkanlıkları, kültürü ve gelenekleri terk etmesinin mümkün olmamasıdır. Formel kuralların olmadığ 1 toplumlarda düzenin oluşmasını sağlayan enformel kurallar olmaktadır. Özellikle küçük kabile topluluklarında yaşayan bireyler arasında yaşanacak olası bir tehlike durumunda bu toplulukta yaşayan herkes olumsuz etkileneceği için bireyler herkesin yararına olacak kuralların var olduğu düşüncesiyle bu kurallara riayet etmekte ve böylece enformel yapılar meydana gelerek meşruiyet kazanarak varlı̆̆ını sürdürmektedir. Dolayısıyla enformel kurallar kültür denilen mirasın bir parçası olarak taklit, sözlü gelenek ve öğrenme yoluyla nesilden nesile aktarılarak varlığını sürdürürken, formel kurallar bir takım düzenlemeler doğrultusunda oluşmakta ve uygulanmaktadır.

North'a göre, kurumlar ile ilgili teoriler ele alınırken içsel ve dışsal olmak üzere iki açıdan incelemek önem arz etmektedir. Kurumlar dışsal olarak değerlendirildiğinde, toplumdaki davranışsal düzenlemeler veya rutinler iken; içsel olarak değerlendirildiğinde ise, tekrarlanan sosyal etkileşim sorunlarında paylaşılan çözümleri içermektedir (Mantzavinos ve diğerleri, 2004: 77). North'a göre kurumların toplumsal hayatta üstlendiği önemli bazı rolleri bulunmaktadır. Öncelikle kurumlar bireyler arasında düzenli olarak tekrarlanan etkileşimleri düzenlemektedir. Bunun yanı sıra kurumlar sadece bireysel tercihlerin etkileşim alanını sınırlamakla kalmamakta aynı zamanda göreli fiyat değişimlerini de azaltmaktadır. Kurumlar bireylerin etkileşimleri ile ortaya çıkan, gelişen, bireyleri caydırıcı veya teşvik edici gelenek ve kurallardır (North, 1986: 231). Dolayısıyla kurumlar, düzenli olarak yapılan bu davranış kalıplarını içermekte ve bu davranış kalıplarının ayak izlerini göstermektedir.

Douglass C. North, kurum olgusunun tanımını yaparken, organizasyon olgusu ile arasında herhangi bir kavram karmaşasına neden olmamak amacıyla ikili bir ayrıma gitmiştir. Ona göre, kurumlar organizasyonların oluşmasını teşvik edici yapılardır. Örneğin, ekonomik örgütler, siyasi kuruluşlar ve eğitim kuruluşları gibi kurumlar; firmaları, siyasi partileri ve üniversiteler gibi organizasyon yapılarını teşvik etmektedir (Mantzavinos ve diğerleri, 2004: 77). 
Organizasyonlar ise, oyunun oyuncularıdır ve kurumların oluşumunu etkileyerek, kendi de etkilenmektedir. Bu yüzden, oyuncular (organizsayon) ile oyunun kuralları (kurumlar) arasında sürekli bir etkileşim bulunmaktadır. Organizasyonlara örnek olarak; siyasi gruplar (siyasi partiler, senato, şehir meclisi, düzenleyici aracılar), ekonomik gruplar (şirketler, sendikalar, kooperatifler, aile çiftliği), sosyal gruplar (kiliseler, klüpler) ve eğitici gruplar (okullar, üniversiteler, mesleki eğitim merkezleri) verilebilmektedir (Mendelski, 2006: 85). Özetle, kurumlar formel ve enformel kurallar ve bunların uygulayıcı özelliklerinden oluşan oyunun kuralları iken; organizasyonlar ise, oyunun oyuncuları anlamına gelmektedir. Bu oyuncular bazı ortak hedefleri (ekonomik, siyasal vb.) gerçekleştirmek isteyen bireylerden oluşmaktadır ve organizasyonların asıl amacı olan "varlığını devam ettirebilme"sine hizmet etmektedirler. Çünkü dünyadaki bütün organizasyonlar kıttır ve bu nedenle yarış içerisindedirler (North, 2005: 3).

Yeni kurumsal iktisatçı olan North, kurumsal çevre ve kurumsal düzenleme kavramlarını de birbirinden ayırmaktadır. Kurumsal çevre; ekonomik ve siyasi faaliyetleri yöneten siyasi, sosyal ve hukuki temelli kurallar setidir. Bunlar, hem formel kurallar (anayasalar, yasalar, mülkiyet hakları) hem de enformel kurallar (sosyal düzenler, normlar) dır. Diğer bir deyişle North, kurumsal çevreyi; üretimin, değişimin ve bölüştürmenin temelini oluşturan, siyasi, sosyal ve hukuki temelli kurallar seti olarak tanımlamaktadır. Seçimleri düzenleyen kurallar, mülkiyet hakları ve sözleşme hakları kurumsal çevreye verilecek örneklerdir. Kurumsal düzenleme ise, işbirliği veya rekabet ile yönetilen ekonomik birimler arasındaki düzenlemedir. Bu düzenleme, üyelerinin işbirliği içinde olduğu bir yapı ya da kanun veya mülkiyet haklarında değişikliğe neden olabilecek bir mekanizma sağlanmaktadır. Kurumsal düzenlemeler organizasyonların detayları ile ilgili iken, kurumsal çevre hem kamu hem de özel sektörde oyunun kurallarını belirleme ile ilgilidir (Williamson, 1990: 64-65). Yani, kurumsal çevrenin içerisinde kurumsal düzenlemeler bulunmaktadır.

\section{MÜLKIYYET HAKKI-İSLEM MALIYYTİ-EKONOMIK PERFORMANS İLIŞKISSI}

Mülkiyet hakk1 ve işlem maliyetleri; Yeni Kurumsal İktisatta ele alınan ve önem arz eden konular arasında yer almaktadır. Mülkiyet hakları teorisi; iktisat literatüründe Ronald Coase tarafindan 1960 yılında kaleme alınan "Sosyal Maliyet Sorunu" (The Problems of Social Cost) adlı çalışması ile gündeme gelmişve daha sonra Armen Alchian'ın 1965 yılında yazdığı "Mülkiyet Haklarının İktisadı (Some Economics of Property Rights) ve Harold Demsetz'in 1967 yılında yazdığı "Mülkiyet Hakları Teorisine Doğru" (Toward a Theory of Property Rights) adlı çalışmalar ile geliştirilmiştir. Ayrıca Alchain ve Demsetz, 1973 yılında beraber kaleme aldıkları "Mülkiyet Hakları Paradigması"(The Property Right Paradigm) adlı çalışma ile de mülkiyet haklarının yapısı ve gelişimine ilişkin önemli katkılar sağlamıştır. Mülkiyet hakkı kavramı ile bağlantılı olan işlem maliyetleri teorisi ise, ilk kez Ronald H. Coase'un 1937 yılında yayınlamış olduğu "Firmanın Doğası" (The Nature of Firm) adlı çalışması ile ele alınmıştır. İşlem maliyetleri iktisadı ile ilgili literatürü Coase'dan sonra geliştiren bir diğer iktisatçı Oliver Williamson olmuştur. Oliver Williamson 1975 yılında yazdığ "Piyasalar ve Hiyerarşiler" (Market and Hierarchies) adlı çalışması ile Coase'un görüşlerine katkı sağlayarak, işlem maliyeti iktisadı akımını geliştirmiştir (Aktan, 2008: 197).

Yeni kurumsal iktisadın önde gelen isimlerinden olan Douglass C. North' a göre mülkiyet hakları; bireylerin kendi emekleri ile sahip olduğu mal ve hizmetler üzerindeki haklardır ve bu haklar kurumsal bir yapının unsurudur (North, 2002: 47). North'a göre, mülkiyet hakları olmadan, tasarruf, yatırım ve buna bağlı olarak fiziksel ve beşeri sermaye birikimini teşvik eden mekanizmalar da ortadan kalkmaktadır (Karaman, 2013: 33). Bu nedenle, bireylerin sahip oldukları mülkiyet haklarının güvence altına alınması konusu ekonomik performans açısından da oldukça önem arz etmektedir. North ve Thomas, mülkiyet haklarının yapısı gereği 
ekonomik büyümeyi teșvik edeceğini söylemiştir. Onlara göre, mülkiyet hakları sosyal üretken faaliyetleri üstlenmek için kullanıldığında, ekonomik büyüme meydana gelmektedir. Bu tür mülkiyet haklarının oluşturulması, belirlenmesi ve yasalaştırılması maliyetli olduğu için, mülkiyet haklarının korunması ve uygulanması hükümetler tarafından yapılmalıdır. Çünkü hükümetler özel gönüllü gruplardan daha düşük bir maliyetle bunu yapabilmektedir (North ve Thomas, 1973: 8).

İşlem maliyetleri ise, değişmenin (mübadele edilen unsurun) temel özelliklerini oluşturan sözleşmelerin uygulanması, hakların belirlenmesi ve korunmasını içeren maliyetlerdir. North'a göre işlem maliyetinin anahtarı bilginin ne kadar pahalı olduğu ile ilgilidir. İşlem maliyeti, mübadele edilen unsurun değerli özelliklerini ölçmenin bedeli ile hakları koruma ve anlaşmaları yürürlüğe sokarak denetlemenin bedelidir (North, 2002: 39). İşlem maliyetleri; piyasadaki ölçülebilen maliyetleri, bilgi edinmek için (sıraya girmek, rüşvet vermek vs. durumlar) harcanan zaman maliyetini, eksik olan denetim ve uygulama yüzünden meydana gelen kayıpların maliyetler toplamını içermektedir (North, 2002: 93). Bu yüzden North, başarılı bir ekonomik gelişme sağlamak amacıyla işlem maliyetlerinin nasıl azaltılabileceği konusu üzerinde durmuştur. Ona göre, işlem maliyetleri önemli olduğu zaman, kurumlar da önemli olmaktadır. (North, 1984: 7). Çünkü, işlem maliyetleri toplumda büyük ölçüde formel ve enformel kurallar tarafından yani kurumlar tarafindan belirlenmektedir. Formel ve enformel kuralların birbiri ile uyumu sağlandığında; karşılıklı etkileşimleri sayesinde oyunun kurallarını korumak ve devam ettirmek için oluşan işlem maliyetleri de azalmaktadır (Pejovich, 1998: 9). Aksi durumda, yani formel ve enformel kuralların çatışması söz konusu olduğunda ise, işlem maliyetleri artmakta ve bunun sonucunda ekonomik büyüme de olumsuz etkilenmektedir (Mendelski, 2006: 8485).Dolayısıyla ekonomik büyümeyi olumlu yönde etkileyebilmek için, kurumsal çerçevenin net bir biçimde oluşturulması ve tanımlanması gerekmektedir.

Düşük işlem maliyeti sağlayan siyasi ve ekonomik kurumlar, ekonomik büyüme altında yatan verimli piyasaları mümkün kılmaktadır. Bilgi maliyeti de dâhil olmak üzere, çok sayıdaki ölçme maliyeti ve sözleşmeleri uygulama maliyeti nedeniyle işlem maliyetleri ortaya çıkmaktadır. Oluşturulacak etkin kurumlar aracılığ 1 ile kişi başına düşen işlem maliyetleri azaltılabilecektir (North, 1992: 30). North ve Wallis milli gelirin yüzde kaçının işlem maliyetlerine harcandığını tespit etmek amacıyla Amerika Birleşik Devletleri'nde bir çalışma gerçekleştirmişlerdir. Yapılan çalışma sonucunda, piyasada gerçekleşen işlem maliyetlerinin (bankacılık, sigortacılık, finansman, toptan ve satışlar ve muhasebeci avukat gibi mesleklerle ilgili maliyetler) milli gelirin \%45'inden fazla olduğu ve bir asır öncesinde $\% 25$ olan bu oranın yükseldiği sonucuna varmışlardır. Bu veriden hareketle North, ekonomideki kaynakların büyük bir kısmının işlem aşamasında tüketilmekte olduğunu vurgulamıştır (North, 2002: 40).

Mülkiyet hakkı ve işlem maliyetleri ile ilgili olan tüm yaklaşımlarda, mülkiyet hakları ve işlem maliyetleri kavramları temelde birbirine bağlı olmaktadır. Mülkiyet hakları eksik olduğunda bireyler mevcut mülkiyet haklarını korumaya veya yenilerini kurmaya çalışacaklardır ve bu nedenle işlem maliyetleri ortaya çıkacaktır. Bu noktada iki ihtimal söz konusu olmaktadır. İlk ihtimale göre, işlem maliyetleri aşırı düzeyde yüksek olacak ve bu durumda mülkiyet haklarının kurulamaması ve bu hakların korunamaması sonucu ortaya çıacaktır. İkinci ihtimalde ise, işlem maliyetleri sıfır olacak ya da faydaları maliyetlerini aşacaktır (Allen, 1999: 899). Fakat North'a göre, mülkiyet yapısı her zaman işlem maliyetlerini içerdiği için mülkiyet haklarının hiçbir zaman tam olarak tanımlanması mümkün olmamaktadır.

\section{KURUMSAL DEĞİŞIMIN NEDENLERİ}

Kurumlar kısıtlayıc1, izin verici veya kurucu olarak görülseler de önemli olan onların nasıl değiştiği sorusunun cevabını bulmaktır. Kurumsal formların belirlenmesinde miras, atalet 
ve yol bağımlılığı önemli faktörlerin başında gelmektedir. Kurumların nasıl ve neden bozulduğu ya da hangi şartların kurumların yeniden icat edilmesi için firsatlar yarattığı gibi soruları anlayabilmek için öncelikle kurumların nasıl değişim gösterdiği hakkında genel bir bakış açısıyla değerlendirme yapılması gerekmektedir.

Geçmişten bugüne kadar geçen süre içerisinde kurumlar, toplumların gelişimini sağladığ 1 için tarihsel olarak özel bir yere sahiptir. Bu nedenle kurumsal değişim sorunu ile baş edilirken özellikle tarihsel bağlamdan hareket edilmesi gerekmektedir. Kurumsal değişim göreli fiyatlarda veya tercihlerde meydana gelen bir değişim sonrasında oluşmaya başlamaktadır (Gagliardi, 2008: 420-422). Birer iktisadi aktör gibi davranan kuruluşlar, gerçekleştirdikleri işlemler ile kurumların değişiminde rol oynamaktadır. Değişimi tetikleyen diğer faktörlere bakıldığında ise; demografik yapı, bilgi birikimi (teknoloji) ve ideoloji gibi unsurlar karşımıza çıkmaktadır (Kama, 2011: 185).

Yeni kurumsal iktisat literatüründe kurumsal değişim; işlem maliyetlerinin ve belirsizliğin azaltılması, dışsallıkların içselleştirilmesi, koordineli ve işbirlikçi davranışlardan kaynaklı toplu faydalar üretme yolları şeklinde analiz edilmektedir. Yeni Kurumsal İktisatçı olan Douglass C. North ise, kurumsal değişim dinamiklerini anlamak için iki ana faktöre inanmaktadır. İlki, kurumlar ve organizasyonlar arasındaki simbiyotikilişki (kurumlar tarafından sağlanan teşvik yapısı etrafında gelişmektedir). Yani, organizasyonlar çevrelerine uyumlu hale getirilmekte ve kurumsal değişime neden olmaktadır. İkincisi, bireylerin değişen firsatları algılayarak reaksiyon gösterdiği geri bildirim süreci sonucunda ortaya çıkan kurumsal değişim (Hira ve Hira, 2000: 273).

Douglass North'a göre kurum ve kuruluşlar arasında gerçekleşen sürekli etkileşim; kurumsal değişimin anlaşılmasının temel anahtarıdır. Kurumsal değişim; uygulama etkinliğinin yanı sıra formel ve enformel kuralların değişmesinin de bir sonucudur. Ona göre, formel kurallar; örgütler veya bireyler tarafından bilinçli olarak siyasi süreç boyunca değiştirilmektedir. Enformel kurallar ise formel kurallardan farklı bir süreç yaşamaktadır. Yani, enformel kurallar önceki formel kuralların uzantıları olarak evrimleşerek hayatta kalmaktadır. North, kurumsal değişimin daha derin bir nedeni olarak göreli fiyatlardaki (emek / sermaye oranı, bilgi maliyetlerindeki değişimler, teknolojideki değişiklikler gibi faktör fiyatlarının oranında değişmeler) değişikliklerden bahsetmektedir. Kurumsal değişim aşamalı olarak meydana gelmekte ve insan etkileşiminin aşamalı bir süreci olarak devam etmektedir. Ayrıca kurumsal değişim insanların tercihlerindeki değişimlere de bağlı olmaktadır. Bu nedenle, insanların ideolojileri, inanç sistemleri ve düşünceleri de kurumsal değişim üzerinde etkili olan faktörlerdendir. North kurumsal değişimin ülkeden ülkeye niçin farklılık gösterdiğini de yaptığı çalışmalarla açıklamıştır. Ona göre, her ülkenin kendine ait bir tarihi yol bağımlılığı (historicalpathdependency) vardır. Diğer bir deyişle, bir ülkeye özgü olaylar ve tepkiler farklı kurumsal ve ekonomik yapının ortaya çıkmasına yol açmaktadır. Kurumsal değişimin bu tarihi yolu; geribildirimler (ölçek ekonomileri, dışsal ağlar) tarafindan güçlendirilmektedir. Her ülkenin izlemiş olduğu tarihi yol bağımlılı̆gının kaynakları ise formel kurallar ve bu kurallarla etkileşim içinde bulunan enformel kurullardır. $\mathrm{Bu}$ nedenle Douglass $\mathrm{C}$. North'un kurumların oluşumu veya değişimi hakkındaki görüşleri; ekonomik durgunluk veya ekonomik büyümenin sebebini anlamak için önem arz etmektedir (Mendelski, 2006: 85).

North, değişimin kaynağınıgöreli fiyatlardaki değişim ve tercihler olarak kabul ederken, değişimin öznesinin ise kurumsal yapıda yer alan teşviklere göre hareket eden bireysel girişimciler olduğunu söylemektedir. North'un ifadesiyle:" Kurumlar değişir ve göreli fiyatlardaki temeldeğişimler, bu değişimin en önemli kaynă̆ıdır. İktisatçı olmayanlar için değişen görelifiyatlara bu kadar ă̆ırlık vermek anlaşılmayabilir. Ancak göreli fiyat değişimleri insanetkileşimlerinde bireylerin teşviklerini değiştirir, bu tür değişimin bir diğer kaynăgl dazevklerdeki değişimdir". North'un ifadesi yorumlandığında, kurumsal değişimin öncelikle 
göreli fiyatlardaki değişim ile gerçekleştiğini ve mevcut fiyat değişimlerinin de bireylerin zevk ve tercihlerinin değişmesine neden olduğu anlaşılmaktadır. Zevk ve tercihlerde meydana gelen değişimlere bağlı olarak da bireysel girişimcileryeni teşviklerden yararlanmak amacıyla sahip oldukları kuruluşlarını değiştirmeyi tercih etmektedir. Dolayısıyla, kurumsal değişim halkasının ilk basamağını göreli fiyatlarda yaşanan değişim oluştururken, buna bağlı olarak devam eden silsilenin ikinci basamağında zevk ve tercihlerde değişim, üçüncü basamağında kuruluşlarda değişim ve tüm bu değişimler sonucunda halkanın son basamağı olan kurumsal değişim ortaya çıkmaktadır (North, 2002: 108-110)

North, kurumsal değişimde enformel kurallara merkezi bir rol vermektedir. Çünkü formel kurallar; örgütler ve bireysel girişimciler tarafindan kasıtll eylemler sonucunda bir siyasi süreç boyunca değişmektedir. Formel kuralların değişikliğinin ardından enformel kurallar da yavaş yavaş önceki formel kuralların uzantıları olarak evrimleşmiştir ve değişim ile hayatta kalmıştır. North'un düşüncesine göre kurumsal değişim genellikle ani gelişmekten ziyade, artan birçok küçük değişiklikler sonucunda zamanla büyük değişikliklerin birikimi olarak gerçekleşmektedir (Kingston ve Cabellero, 2009: 168). North'a göre, kurumsal değişimi anlamak için öncelikle kurumların özelliklerinin bilinmesi gerekmektedir. Kurumların temel işlevi göreli fiyat değişikliklerinin etkisini azaltmaktır. Çünkü, kurumsal değişimin temel kaynağ1 göreli fiyatlarda köklü ve kalıcı değişikliklerdir (North, 1989: 241). North'a göre, göreli fiyatlardaki değişimin itici güçleri, insan eylemlerinden kaynaklanan hem dişsal hem de içsel kökenlerdir. Göreli fiyatlar değiştikçe aktörler de davranışlarını değiştirmekte ve sözleşmeleri tekrar pazarlık konusu yapmaktadır (Steele, 1995: 452). North, başarılı bir kurumsal değişimin sadece devlet teorisi ve demografik değişim teorisi olmadığını, aynı zamanda ideolojik davranış teorisi ve teknik bir değişim teorisi olduğunu savunmaktadır (Eggertsson, 1990: 345).

North'a göre, ideolojiler ile tercihler; tarihsel ve coğrafi olarak kurumsal değişim süreçlerinin köklerinde bulunmaktadır (Rossiaud ve Locatelli, 2010: 19). Dışsal değişiklikler (toplam nüfus, bilgi veya ideolojik değişiklikler) sayesinde aktörler; alternatif kurumsal düzenlemeleri daha iyi anlamakta ve kurumsal değişim gerçekleşmektedir. Çünkü kurumsal değişim; ekonomik ve politik piyasalar arasındaki geribildirim şeklinde olmaktadır. Bu nedenle, işlem maliyetlerinin yüksek olması (siyasi ve ekonomik) sonucunda verimsiz kurumlar uzun süre varlığını devam ettirememektedir (Richter, 2005: 176). Kurumsal değişimin nedenlerini Şekil 1 yardımı ile özetlemek gerekirse,

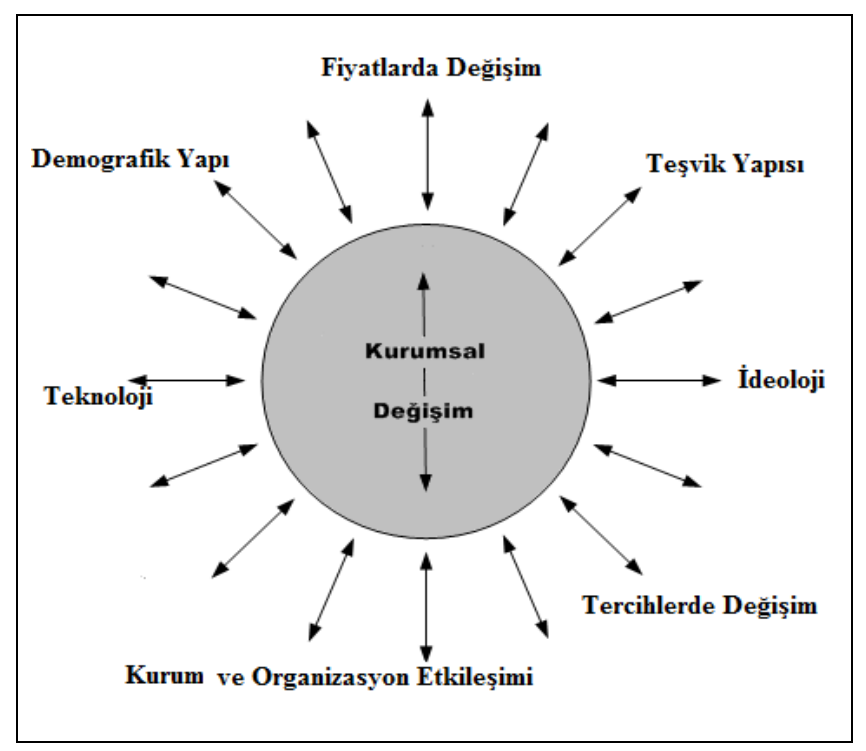

Şekil 1: Kurumsal Değişimin Nedenleri

Kaynak: Tarafimca oluşturulmuştur. 
North'a göre kurumsal değişimin analitik çerçevesi beş başlık altında toplanmaktadır. Bunlar (North, 1992: 15),

1. Kurum ve organizasyon arasındaki sürekli etkileşim ile ekonomideki kıtlık ve buna bağlı olarak ortaya çıkan yarış kurumsal değişimin anahtarıdır.

2. Yarış, organizasyonların varlıklarını sürdürebilmeleri için devamlı olarak yeni yeteneklere yatırım yapmaya ve bilgi edinmeye zorlamaktadır.

3. Kurumsal çerçeve maksimum getiriyi sağlayacak bilgi ve yetenek çeşitlerinin belirlenmesinde teşvik yapısı sağlamaktadır.

4. Algılar oyuncuların zihinsel yapısına bağlı olarak oluşmaktadır.

5. Kurumsal bir matrisin ekonomik kapsamı ve ağ dışsallıkları kurumsal değişimi karşı konulmaz ve bağımlı bir hale getirmektedir.

Douglass C. North'a göre, kurumsal değişim çeşitli alanlarda (şirketlerde, kaynaklarda, süreçte ve yöntemde) gerçekleşmektedir. Buna bağlı olarak, kurumsal değişim teorisi; özellikle sosyal bilimler ve ekonomide daha fazla ilerleme kaydedilmesi için temel faktördür. Değişimin kaynakları; girişimciler tarafından algılanan firsatlar olduğu için göreli fiyatlardaki değişim kurumsal değişim tarihinin en sık görülen dış kaynaklarından birisi olmuştur. Bunun yanı sıra, zevklerdeki değişimler ile formel ve enformel kurallardaki değişiklikler de kurumsal değişimin gerçekleşmesinde etkili olan faktörler arasında yerini almıştır (North, 1994a: 4-6).

\section{KURUMSAL DEĞİŞIM VE EKONOMIK PERFORMANS İLISŞKISİ}

Yeni Kurumsal İktisatçıların önde gelen isimlerinden birisi olan Douglass C. North'a göre, kurumlar ekonomik performansın ana belirleyicisidir. Formel veya enformel yaptırımlar ise bir milletin kurumsal çerçevesinin ayrılmaz bir parçasıdır ve ekonomik performans farklı1ıklarını açıklayan en önemli unsurlardandır (Yeager, 1997: 1-3). Yeni Kurumsal İktisat alanında yürütülen sayısız çalışmalar ışığında, ülkelerin sahip olduğu kurumların özelliklerine bağlı olarak farklı ekonomik performansların ortaya çıktığı sonucuna varılmıştır (Gagliardi, 2008: 417).

Yeni kurumsal iktisatçılara göre, bazı toplumlar kötü ekonomik performans sürecinden çıkamamaktadır. $\mathrm{Bu}$ iktisatçılara göre, toplumların kötü ekonomik performansta takılıp kalmalarının ise üç sebebi bulunmaktadır. Birincisi, bazı toplumların belirli bir takım izlediği politika ve alışkanlıkları bırakıp başka bir politikaya geçmesi çok zor olmaktadır. Çünkü organizasyonların uyum sağladıkları mevcut yapılarından başka bir yapıya geçmesi söz konusu olduğunda değişiklikler çatışmaya neden olmaktadır. İkincisi, nedenler ve sonuçlar hakkındaki enformasyonun zayıf olması ve ekonomilerin çok karmaşık olmasıdır. Başka bir deyiş̧le, başarılı bir ekonomi tarihi incelendiğinde bile, kurumları başarıya ulaştıran faktörlerin ne olduğu kesin olarak bilinememektedir. Üçüncü neden ise, enformel kurumların değişimlerinin yavaş olmasıdır. Güvenin az olduğu, ahlak sisteminin zayıf olduğu kültürlerde ekonomik değişim yüzy1llar geçtiği halde gerçekleşemeyebilir(Yeager, 1997: 12-13).

North, ekonomik performans ile kurumsal yapı arasında doğrudan bir ilişki kurmaktadır. Çünkü North'a göre, ekonomik ve politik kurumlar, dinler, ideolojiler, dogmalar, kuşaktan kuşağa yayılan mitler ve inançlar ekonomik performansı belirlemeyenönemli faktörlerdir. $\mathrm{Bu}$ nedenle North, ekonomik performansın temelinde formel ve enformel kurulların birleşimi olduğunu ve ülkelerin farklı gelişmişlikderecesi gösterme nedeninin de, her ülkenin farklı kurumsal yapılara sahip olması şeklinde ifade etmektedir. Ekonomik performansı etkileyenbir diğer faktörün ise, ekonomik kurumları tanımlayan ve yaptırımını sağlayan politikalar olduğunu belirtmektedir. Çünkü ona göre, örneğin, gümrük duvarlarının yaratılması, kölelerin 
sömürülmesi ve tekellerin oluşturulması gibi uygulanan politikalar ekonomik açıdan olumlu firsatlar sağlayabileceği gibi bazen de bu politikalar öngörülmeyen negatif sonuçlar doğurabilmektedir. Yani North'un ifade ettiği gibi, kurumlar yamalı bir bohça gibidir ve sahip olunan kurumsal yapıya göre üretkenliğin artmasına veya azalmasına neden olabilmektedir. Ekonomik performansı etkileyen üçüncü faktör ise, uzun dönemde büyümenin anahtarı olarak kabul ettiği uyum etkinliğidir. Bir diğer deyişle, politik ve ekonomik kurumların yapısının; ani şoklara karşı esnek olması ve bunlar karşısında başarılı bir şekilde değişip uyum sağlayabilmesi gerekmektedir (Güvel, 1998: 264-266).

Douglass C. North'a göre, ekonomik performans toplum tarafindan takip edilen kuralların veya kurumların bir işlevidir. Kurumsal çerçeve, ekonomik aktörlerin karşılaş̧tığı sınırlamaları ve teşvikleri belirlemektedir (Steele, 1995: 447). Douglass C. North kurumların ekonomik performans üzerindeki etkisi değerlendirirken formel ve enformel kuralları ayrı ayrı ele almıştır. Ona göre, formel kurallar; kurumsal yapının önemli bir parçası olmakla birlikte ekonomik performansı olumlu olarak etkileyebilmesi için enformel kurallar ile uyum içinde olması gerekmektedir. Formel ve enformel kurallar arasında uyumsuzluk meydana geldiğinde ise ortaya çıkan kurumsal yapı ekonomik performansı olumsuz yönde etkilemektedir.

Kurumlar, (kullanılan teknoloji ile birlikte) işlem ve dönüşüm (üretim) maliyetlerini belirleyerek ekonomik performans1 etkilemektedir (North, 1994a: 2-3). İşlem maliyeti denilen kavram; mübadele edilenunsurun özelliklerinin ölçülmesi ve belirlenmesi ile hakların korunmasının ve anlaşmaların yürürlüğe koyma ve denetlenmesinin bedelidir (North, 2002: 39).Dolayısıyla, işlem maliyeti; mülkiyetin edinimi ve sonrasında ortaya çıkan haklar ile ilgili olarak ortaya çıkmaktadır. Bu bağlamda, ekonomik performansın olumlu etkilenmesi için işlem maliyetinin azaltılması gerekmektedir. İşlem maliyetinin azaltılması ise, mülkiyet haklarının açık bir şekilde tanımlanması ve korunmasına bağlıdır. Douglass C. North'a göre, bir toplumun genel kurumsal yapısı ve onun mülkiyet haklarına ilişkin düzenlemeleri de toplumlar arasındaki ekonomik performans değişikliklerinin nedenini açıklamaktadır (Libecap, 1992: 227). Douglass C. North ve Bob Thomas 1973'te "Batı Dünyasının Yükselişi" isimli çalışmalarında mülkiyet haklarını ekonomik performansın merkezine yerleştirmiştir. North, mülkiyet haklarının uygulanması meselesini güvenilir bir sözleşmenin ve ticaretteki potansiyel kazançların fark edilmesinin önündeki engellerin merkezi olarak değerlendirmiştir (North, 1993b: 12). Dolayısıyla, mülkiyet haklarının içeriğinde ince değişiklikler yapılarak makro-ekonomik performans değiştirilebilmekte ve ekonomik büyüme ya da durgunluğa neden olunabilmektedir (Gagliardi, 2008: 40).

North'a göre geliştirilecek kurumsal bir teori ile ülkeler arasında tarih boyunca görülen ekonomik performans çeşitliliği açıklanabilmektedir. Ona göre, insani ilişkiler ve işbirliği bazı ülkelerde ekonomik büyümeye neden olurken bazılarında ise durgunluğa hatta küçülmeye neden olmaktadır. North bunun nedenini teşviklere bağlamaktadır. Bu teşvikler insan eylemlerini şekillendirerek diğerlerinden farklı bir yola girmelerini sağlamaktadır. Teşvikler bireylerin karşı karşıya kaldıkları kısıtlamalarla yakından ilgilidir. Toplum tarafından takip edilen bu kısıtlamalar ile kurallar ve kurumların varlığı ise; ekonomik seçimlerin gerçekleştiği çerçeveyi oluşturmaktadır (Steele, 1995: 448-449). North'a göre, bir kurumun performansı bir topluluğun buna nasıl tepki vereceğini bağlı olarak değişmektedir. Bu nedenle, topluluk özellikleri kurumsal performans1 etkileyebilmektedir (Bednar ve Page, 2006: 1). Toplulukların kurumsal performansa etkisini Şekil 2 yardımı ile açıklamak gerekirse, 


\begin{tabular}{lll|} 
& $\underline{\text { Topluluk 1 }}$ & $\underline{\text { Topluluk 2 }}$ \\
Period 1: & A & A \\
Period 2: & B & B' \\
Period 3: & C (iyi performans) & C (kötü performans) \\
\hline
\end{tabular}

Şekil 2: Toplulukların Kurumsal Performansa Etkisi

Kaynak: (Bednar ve Page, 2006: 8).

Şekil 2'de topluluk 1 ve topluluk 2 olmak üzere iki ayrı grup bulunmaktadır. İlk durumda (period 1) her iki topluluğun kurumu A iken, ikinci durumda (period 2) kurumlar B ve B' olmaktadır. Toplulukların farklı olmasından dolayı topluluk 2'de ortaya çıkan kurumsal kültür ile topluluk 1'de ortaya çıkan kurumsal kültür farkl1lık göstermektedir. Topluluklara yeni bir stratejik ortam (C) tanıtıldığında ise, iki toplumun buna vereceği tepki; farklı kurumsal kültürler nedeniyle aynı olmamakta ve farklı ekonomik performanslar ortaya çıkmaktadır.

North, ekonomik büyümenin gerçekleşmesini toplumun elde edeceği bilgiye, yeniliklere ve yaratıcı faaliyetlere, dışsal şoklara ve yol bağımlılığı gibi çeşitli faktörlere dayandırmaktadır. North'a göre, kurumlar alışveriş yapısın1, işlem ve dönüşüm maliyetlerini belirlemekte ve dolayısıyla ekonomik faaliyette bulunanların karlılığını etkilemektedir. $\mathrm{Bu}$ mekanizma kurumların uzun vadeli ekonomik performansının altında yatan belirleyici faktör olmaktadır. Bu nedenle bazı ülkelerin nasıl ekonomik performans açısından başarılı ve diğerlerinin neden başarısız olduğu açıklanabilmektedir (Gagliardi, 2008: 421-422). Diğer bir deyişle, kurumsal çerçeve ekonomik performans süreci üzerinde etkili olmaktadır. Ekonomik performans süreci Şekil 3 yardımı ile gösterilecek olursa,

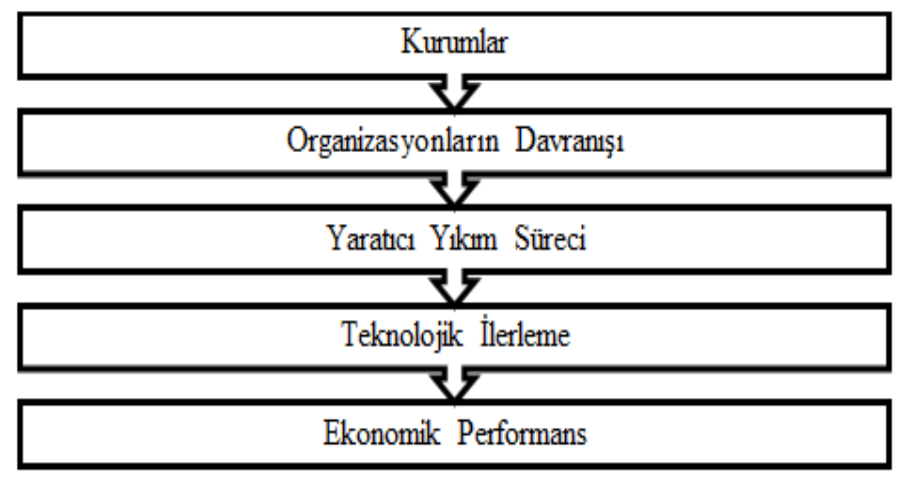

Şekil 3: Ekonomik Performans Süreci

Kaynak:(Yeager, 1997: 11).

Kurumlar, kurallar, normlar ve bunların uygulama özelliklerinin karışımı ekonomik performansı belirlemektedir (North, 1993a: 7). Davranış normları, sözleşmeler, davranış kuralları gibi enformel kısıtlamalar iyi bir ekonomik performans için gerekli bir şart olmakla birlikte yeterli bir şart değildir. Bazı toplumlar bazen olumsuz veya istikrarsız politik kurallarla bile, istenilen ekonomik büyümeyi sağlayabilmektedir. Burada önemli olan olumsuz politik kuralların uygulanma derecesidir. İyi bir ekonomik performans için gerekli olan faktör teknolojik ve demografik değişikliklerin yanı sıra sistemdeki şoklara göre kendini ayarlayabilen esnek kurumsal bir matrisin varlığıdır (North, 1993a: 8). Ayrıca, devletler de ekonomik kuralları tanımlayıp uygulayan kurumlar olduğundan, ülkelerin yönetim şekilleri de ekonomik 
performansı önemli ölçüde şekillendirmektedir. Devletin yapısı ile kurumlar arasındaki ilişkiyi bir matris yardımıyla açıklamak gerekirse,

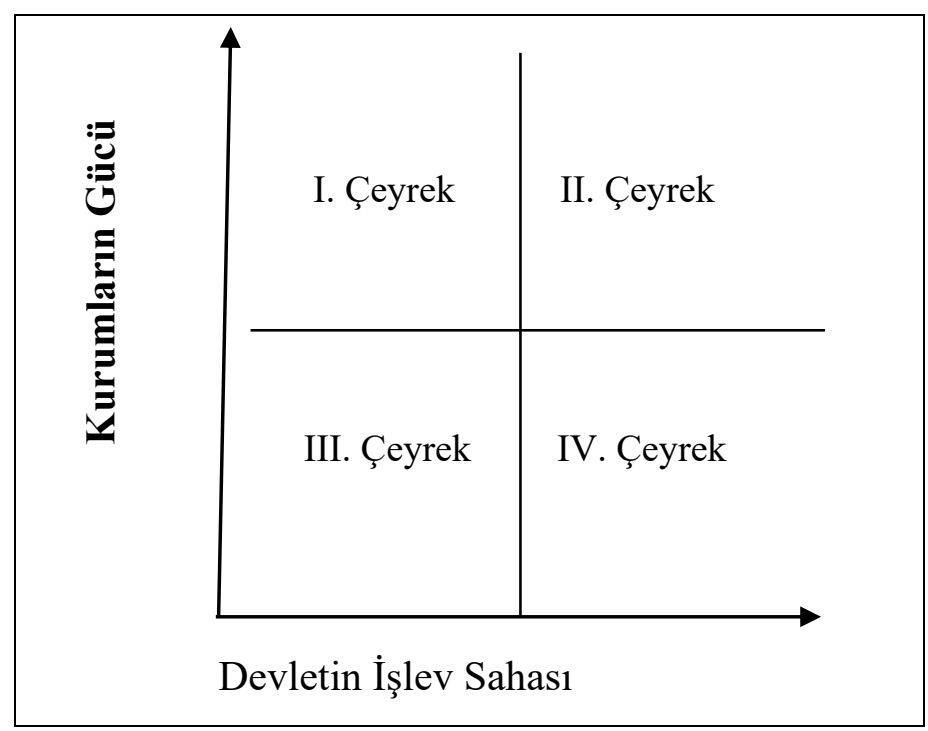

Şekil 4: Devlet Olma ve Etkinlik

Kaynak:(Fukuyama, 2005: 23).

Şekil 4'deki matriste kurumsal etkinliğin derecesini gösteren $\mathrm{Y}$ ekseni ile devletin sınırlarını (işlev sahası) gösteren X ekseni dört farklı alanı ifade etmektedir. I. çeyrekteki alan sınırlı devlet anlayışı ve güçlü kurumların yer aldığı bir alandır (Fukuyama, 2005: 24). Bu alanda yer alan bir devlet orjinden yukarıya doğru ilerlediği yani etkin kurumlara sahip olduğu için ekonomik performansı da artmış olacaktır. North'a göre güçlü bir kurumsal yapı ekonomik faaliyetleri teşvik edici etki göstermektedir. Çünkügüçlü kurumlara sahip bir devlette mülkiyet hakları korunmakta, sözleşmelere uyulmakta, düşük işlem maliyetleri ve etkin bir bürokrasi bulunmaktadır. Bu sayede bireyler iktisadi etkinliklerini artırarak üretken yatırımlara yönelmekte ve ekonomik performans olumlu yönde etkilenmektedir. IV. çeyrek ise I. çeyrektekinin aksine ekonomik performans açısından etkin olmayan bir alandır. Bu alanda devletin işlevleri aşırı bir şekilde artarken, kurum kalitesi en düşük seviyede olmaktadır (Fukuyama, 2005: 24-25). Yani, bu alan devletin etkin bir şekilde yer aldığı ve bu nedenle politik çıkarlar doğrultusunda hareket edilmeye en müsait alan olduğu için kurumsal yapıda güvenilirlik ve şeffaflık kalmayacak ve bu nedenle bireylerin yatırım, tasarruf gibi iktisadi faaliyetlere olan istekleri azalarak ekonomik performans olumsuz etkilenecektir.

II. çeyreğe baktığımızda ise, güçlü bir kurumsal yapı olmasına rağmen aynı zamanda devlet faaliyetlerinin de yoğun olduğu bir alan görülmektedir. Yani kurumlar ne kadar güçlü bir yapıya sahip olsalar da devlet müdahalesinin fazla olmasından dolayı istenilen seviyede bir ekonomik performans elde edilemeyecektir. III. çeyrek ise hem kurumların gücünün hem de devletin sınırlı olduğu bir alandır. Burada ise, kurumların gücü ve devletin etkinliğinin en az görüldüğü bir alan olmasından dolayı kendi kendine işlemesi söz konusudur(Fukuyama, 2005: 28). Yani, sınırlı bir yetkiye sahip otoritenin elinde birtakım yetkilerin bulunduğu fakat kurum kalitesinin düşük olmasından sahip olduğu yetkiyi istediği şekilde kullanabileceğinden dolayı ekonomik büyüme sağlanamayacaktır. North'un ifade ettiği gibi kurumlar yamalı bir bohça 
olduğu için üretkenlikte ve ekonomik büyümede ortaya çıkartacağı etkilerde farklı olmaktadır. Sonuç olarak, uzun vadeli ekonomik büyümenin gerçekleştirilebilmesi için devlet kurumlarının gücünün artırılması ve devletin faaliyet sahasının daraltılması gerekmektedir yargı verilmiş.

Kurumsal değişim ve ekonomik performans ilişkisini Douglass C. North perspektifinden kısaca özetlemek gerekirse, Douglass C. North, ekonomik değișimi anlamak ve analitik bir çerçeve oluşturabilmek için kurumsal bir yaklaşım ile konuyu ele almış ve üç unsurun varlığ ile bunların neden olacağı sonuçlarından bahsetmiştir (North, 1994b: 366-367),

1. Ekonomik performansı şekillendiren resmi kuralların, resmi olmayan normların ve uygulama özelliklerinin karışımıdır. Kurallar bir gecede değişebilirken, enformel normlar genellikle sadece kademeli olarak değişmektedir. Bir dizi kurala "meşruiyet" kazandıran normlar olduğu için, değişim her zaman istenildiği kadar gerçekleşmemekte ve performans beklenenden farklı olmaktadır. Başka bir ülkenin resmi kurallarını benimseyen ülkeler, farklı enformel normlar ve uygulamalardan dolayı çok farklı performans özelliklerine sahip olacaklardır. Bu durumun örneği ise, başarılı Batı pazar ülkelerinin formel politik ve ekonomik kurallarının, üçüncü dünya ve Doğu Avrupa ülkelerine aktarılması sonucunda iyi bir ekonomik performansa sahip olamamasıdır. Özelleştirme, düşük ekonomik performansı çözmek için çare değildir.

2. Politikalar; ekonomik performansı önemli ölçüde şekillendirmektedir. Çünkü politikalar ekonomik kuralları tanımlamakta ve uygulanmasını sağlamaktadır. Yani, politikaların belirlendiği kurumsal yapıya bağlı olarak (devlet, yönetim şekli vb.) ekonomik kurallar belirgin biçimde şekillenmektedir. Dolayısıyla, ekonomik büyüme otokratik rejimlerle kısa vadede gerçekleşebilirken, uzun vadeli ekonomik büyüme hukukun üstünlüğünün gelişmesini gerektirmektedir. Enformel kısıtlamalar (normlar, kurallar ve davranış kuralları) bazen istikrarsız veya olumsuz politik kurallarla bile ekonomik büyüme sağlayabilmektedir. Önemli olan bu tür olumsuz kuralların uygulanma derecesidir.

3. Uzun vadeli büyümenin anahtarı tahsis etkinliğinden ziyade uyum etkinliğidir. Başarılı siyasi / ekonomik sistemler; şok ve değişiklikleri atlatabilen, başarılı evrimin bir parçası olan esnek kurumsal yapıları geliştirmiştir.

\section{SONUÇ}

Douglass C. North kurumlar1; formel ve enformel kurallar ve bunların uygulayıcı özelliklerinden oluşan oyunun kuralları olarak ifade etmektedir. North'a göre enformel kurallar toplumlarda bilgi ve kültürün bir parçası olarak aktarılmakta ve varlığını sürdürmektedir. Buna bağlı olarak, enformel kurallar tekrarlanan insan etkileşimleri ile oluşmakta ve toplumlar tarafından meşruiyet kazanmış davranış normlarını içermektedir. Formel kurallar ise sosyal, ekonomik ve politik sınırlandırmaları belirten yazılı kurallardan oluşmaktadır. Formel ve enformel kuralların yaptırım mekanizmaları ise bu kuralların uygulanmalarını sağlamaktadır. North kurumların insan etkileşimlerini düzenlediğini, karşılıklı ilişkilerde belirsizlikleri, göreli fiyat değişimlerini ve işlem maliyetlerini azalttığını, mülkiyet haklarının tanımlanması ve korunmasını sağladığını ve ülkelerarası ekonomik performans farklılıklarının kaynağı olduğunu vurgulamıştır. Bu nedenle North'a göre kurumlar toplumlarda politik, sosyal veya ekonomik değişimleri teşvik ederek, mülkiyet hakları, işlem maliyetleri, kurumsal değişim ve ekonomik performans üzerinde etkili olmaktadır.

North, kurumlar ve ekonomik performans arasındaki ilişkiyi cliometrics çalışmalar ile ortaya koyması ve kurumlara merkezi bir rol vermesi açısından iktisat tarihine yeni bir bakış açısı getirmektedir. Ülkelerin zaman içerisinde farklı ekonomik performanslara sahip olmasının temelini kurumsal farklı1ıklara dayandırmaktadır. Kurumları ekonomik performansı belirleyen temel faktör olarak kabul ederken aynı zamanda kurumların mülkiyet hakları ve işlem maliyeti 
konuları ile ilişkisine de dikkat çekmektedir. Bunun yanı sıra kurumların ve kurumsal değişimin analizini gerçekleştirirken fiyat teorisine önem vermesi ve göreli fiyat değişimleri sonucunda değişen birey tercihleri ile kurumsal değişim sürecinin yaşandığını savunmaktadır. Kurumların ekonomik performansı olumlu yönde etkileyebilmesi için iyi bir kurumsal çerçeve tasarlanarak, mülkiyet haklarını tanımlayan ve koruyan, sözleșmelerin uygulanabilirliğini sağlayan ve böylece işlem maliyetini azaltan kurumların olması gerekliliğini vurgulamaktadır. North ayrıca kurumlar ve organizasyonlar ile kurumsal çevre ve kurumsal düzen kavramları arasında ayrım yapması ile yeni kurumsal iktisat teorisinde önemli katkılar sunmuştur. Sonuç olarak, Douglass C. North kurallar, kurumlar, işlem maliyetleri, mülkiyet hakları, kurumsal değişim ile kurumların ekonomik performans üzerindeki etkilerini incelediği çalışmaları ve kurumları değerlendirirken iktisat tarihini de ele alarak yaptığı öncü araştırmaları ile Yeni Kurumsal İktisadafarklı bir pencere açmış ve kurumların insan davranışları ile ekonomik performans sürecini etkilemesi nedeniyle önemli bir role sahip olduğunu sonucunu ortaya koymuştur.

\section{KAYNAKÇA}

Aktan, C. C. (2004), Yeni İktisat Okulları, Ankara: Seçkin Yayıncılık.

Allen, D. W. (1999), Transaction Costs, Encyclopedia of Lawand Economics, http://encyclo.findlaw.com/tablebib.html.

Bednar, J. \& Page, S. E. (2006), “Culture, Institutional Performance, and Path Dependence”, eScholaship University of California. 1-35.

Dumludağ, D. (2014),Kurumlar, Kurumsal Değişim ve Ekonomik Kalkınma. Kalkınmada Yeni Yaklaşımlar (ss. 1537). (Ed. Devim Dumludağ ve Ahmet Faruk Aysan). Ankara: İmge Kitabevi.

Eggertson, T. (1990), EconomicBehaviorandİnstitutions, United Kingdom: Cambridge UniversityPress.

Fukuyama, F. (2005), Devlet İnşası: 21.Yüzyılda Dünya Düzeni ve Yönetişim, İstanbul: Remzi Kitabevi.

Gagliardi, F. (2008), "Institutions and Economic Change: A Critical Survey of the New Institutional Approaches and Empirical Evidence", Journal of Socio-Economics, 37(1): 416-443.

Güvel, E. A. (1998),Politik İktisat ve Akll, İstanbul: Alfa Yayınları.

Hira, A. \&Hira, R. (2000), "The New Institutionalism: Contradictory Notions of Change", American Journal of Economics and Sociology, 59(2): 267-282.

Kama, Ö. (2011), “Yeni Kurumsal İktisat Okulunun Temelleri”, Gazi Üniversitesi İktisadi ve İdari Bilimler Fakültesi Dergisi, 13(2): 183-204.

Karaman, K. K.(2013), “Law, Politics and Long Term Economic Development”, (212):29-48.

Kingston, C., Caballero, G. (2009), "Comparing Theories of Institutional Change”, Journal of Institutional Economics, 5(2): $151-180$.

Libecap, G. D. (1992), Douglass C. North, (Ed. W. J. Samules), New Horizons in Economic Thought: Appraisals of Leading Economists, London: Edward Edgar.

Mantzavinos, C., North, D. C. \&Shariq, S. (2004), "Learning, Institutions, and Economic Performance", Perspectives on Politics, 2(1): 75-84.

Mendelski, M. (2006), The Application of Douglass North's Approach to Institutional Change in TransitionEconomies, Donetsk National Technical University Series “Economics”, Donetsk, 84-91.

Milonakis, D. \&Fine, B. (2007), “Douglass North’s Remaking of Economic History: A Critical Appraisal”, Review of Radical Political Economics, 39(1): 27-57.

Myhrman, J. \&Weingast, B. R. (1994), "Douglass C. North's Contributions to Economics and Economic History", The Scandinavian Journal of Economics, 96(2):185-193.

North, D. C. \& Thomas R. P. (1973), The Rise of the Western World: A New Economic History. United Kingdom: Cambridge University Press. 
North, D. C. (1984), “Transaction Costs, Institutions, and Economic History”, Journal of Institutional and Theoretical Economics, 140(1): 7-17.

North, D. C. (1986), “The New Institutional Economics”, Journal of Institutional and Theoretical Economics, 142(1): 230-237.

North, D. C. (1989), "Final Remarks Institutional Change and Economic History", Journal of Institutional and Theoretical Economics, 145(1): 238-245.

North, D. C. (1992), Transaction Costs, Institutions, and Economic Performance, California: An International Center for Economic Growth Publication.

North, D. C. (1993a), “The New Institutional Economicsand Development", http://econpapers.repec.org/RePEc:wpa:wuwpeh:9309002

North, D. C. (1993b), "Institutionsand Credible Commitment", Journal of Institutional and Theoretical Economics, 149(1): 11-23.

North, D. C. (1994a), "Institutional Change: A Framework of Analysis", http://econpapers.repec.org/RePEc:wpa:wuwpeh:9412001

North, D. C. (1994b), “Economic Performance Through Time”, The American Economic Review, 84(3): 359-368.

North, D. C. (2002), Kurumlar, Kurumsal Değişim ve Ekonomik Performans, (Çev. Gül Çağalı Güven), İstanbul: Sabanc1 Üniversitesi Yayınları.

North, D. C. (2005), "Institutions and the Process of Economic Change”, Management International, 9(3): 1-7.

Pejovich, S. (1998), Toward a Theory of the Effects of the Interaction of Formal and Informal Institutions on Social Stability and Economic Development, Germany: University of Potsdam.

Richter, R. (2005), “The New Institutional Economics: its Start, its Meaning, its Prospects”, European Business Organization Law Review, 6(2). 161-200.

Rossiaud, S. \&Locatelli C. (2010), "Institutional Economics", Polinares Working Paper N. 12, September.

Skoog, G. E. (2005), "Supporting the Development of Institutions-Formal and Informal Rules: An Evaluation Theme Basic Concepts", UTV Working Paper 3, Stockholm: Sida.

Steele, C. N. ( 1995), "Discovery, Transaction Costs, and Growth: Essay on Douglass C. North's Institutions, Institutional Change, and Economic Performance", Advances in Austrian Economics, 2: 447-459.

Yeager, T. J. (1997), “The New Institutional Economics and its Relevance to Social Economics”, Forum for Social Economics, 27(1): 1-17.

Williamson, O., E. (1990),“A Comparison of Alternative Approaches to Economic Organization”, Journal of Institutional and Theoretical Economics. 146(1): 61-71. 
Optimum Journal of Economics and Management Sciences, Vo1. 5, No. 2- http://dergipark.gov.trloptimum Yolal-A New Window Opened at Institutional Economy: Evaluation of the Institutions in the Douglass C. North Perspective 